UNIVERSITAS MUHAMMADIYAH MALANG JP2SD (JURNAL PEMIKIRAN

DAN PENGEMBANGAN SEKOLAH DASAR)

http://ejournal.umm.ac.id/index.php/jp2sd

p-ISSN: 2338-1140 e-ISSN: 2527-3043

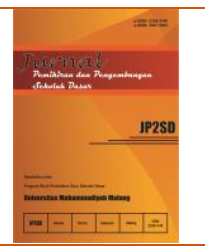

\title{
Pengembangan Buku Ajar IPA SD Melalui Pendekatan Konsep Cinta Keberagaman Suku Bangsa dan Budaya Indonesia
}

\section{Desi Eka Pratiwi}

Universitas Wijaya Kusuma Surabaya, Indonesia Desiekapratiwi364@gmail.com

\begin{tabular}{ll}
\hline INFORMASI ARTIKEL \\
\hline Riwayat: \\
Diterima & 24 Februari \\
& 2020 \\
Revisi & 23 Maret \\
& 2020 \\
Dipublikasikan & 26 April \\
& 2020
\end{tabular}

Kata kunci:

Pengembangan Buku Ajar, IPA SD, Pendekatan Konsep

\begin{abstract}
ABSTRAK
Sebagian besar siswa tidak mampu menjawab soal pada buku disebabkan minimnya penguasaan konsep pada materi yang sedang mereka pelajari. Konsep yang belum matang ditambah dengan soal-soal latihan yang banyak menyebabkan nilai yang diperoleh siswa belum sesuai dengan standar minimal ketuntasan belajar. Tujuan dari penelitian ini adalah untuk mengembangkan buku ajar IPA SD melalui uji kelayakan isi, bahasa, dan kegrafikan. Jenis penelitian menggunakan metode penelitian dan pengembangan model 4D (Four D Model) yang terdiri dari tahap (1) Define (Pendefinisi), (2) Design (Perancangan),
\end{abstract} (3) Develop (Pengembangan), (4) Disseminate (Penyebarluasan). Teknik pengumpulan data menggunakan dokumentasi, wawancara, angket. Jumlah skor yang diperoleh pada uji kelayakan isi sebasar 176 presentase ratarata sebesar 77,19\% dengan kategori baik, uji kelayakan bahasa sebasar 179 dengan presentase rata-rata sebesar $78,50 \%$ dengan kategori baik, uji kelayakan kegrafikan sebasar 359 dengan presentase rata-rata sebesar 85,47\% dengan kategori baik, uji coba terbatas memeroleh presentase rata-rata sebesar 86,93\% dengan kategori buku ajar sudah menunjukkan indikasi baik. Sedangkan pada uji coba luas memeroleh presentase rata-rata sebesar 92,57\% dengan kategori buku ajar sudah menunjukkan indikasi sangat baik sehingga layak untuk digunakan. Kenaikan ratarata dari uji coba terbatas dengan presentase rata-rata sebesar 86,93\% dengan kategori baik, sedangkan pada uji coba luas dengan presentase rata-rata sebesar 92,57\% dengan kategori sangat baik terjadi kenaikan sebesar 5,64\%

\section{ABSTRACT}

Keywords:

Textbook Development,

Elementary School Science,

Concept Approach
Most students are unable to answer questions in books due to the lack of mastery of concepts in the material they are studying. The concept of immature added with many practice questions causes the scores obtained by students are 
Copyright (c) 2020, Desi Eka Pratiwi

This is an open access article under the CC-BY-SA license not in accordance with the minimum standard of learning completeness. The purpose of this study is to develop elementary school science textbooks through content, language and graphic feasibility tests. This type of research uses the method of research and development of the 4D model (Four D Model) which consists of stages (1) Define, (2) Design, (3) Develop, (4) Disseminate. Data collection techniques using documentation, interviews, questionnaires. The number of scores obtained in the content suitability test 176 percent average of $77.19 \%$ with a good category and 179 appropriate language eligibility tests with an average percentage of $78.50 \%$ with a good category. The feasibility test feasibility of 359 with an average percentage average of $85.47 \%$ with a good category. Limited trials obtained an average percentage of $86.93 \%$ with the textbook category already showing good indications. Whereas in the extensive trials, the percentage obtained an average of $92.57 \%$ with the textbook category showing very good indications so that it is feasible to use. The average increase of limited trials with an average percentage of $86.93 \%$ in the good category, whereas in broad trials with an average percentage of $92.57 \%$ with very good categories an increase of $5.64 \%$.

How to cite: Desi Eka Pratiwi. (2020). Pengembangan Buku Ajar IPA SD Melalui Pendekatan Konsep Cinta Keberagaman Suku Bangsa dan Budaya Indonesia. Jurnal Pemikiran dan Pengembangan Sekolah Dasar, Vol 8 No 1, 35-50. doi: https://doi.org/10.22219/jp2sd.v8i1.11903

\section{PENDAHULUAN}

Belajar dan pembelajaran merupakan dua kegiatan yang tidak dapat terpisahkan. Belajar merupakan kegiatan yang dilakukan secara terus menerus untuk mendapatkan suatu berita, informasi atau data/fakta yang belum diketahui sebelumnya. Sedangkan pembelajaran merupakan suatu kegiatan yang dilakukan oleh dua orang atau lebih yang didalamnya terdapat kegiatan belajar. Dalam kegiatan pembelajaran terjadi transfer ilmu/pengetahuan dari narasumber ke audience. Kegiatan belajar mengajar yang biasa disebut KBM merupakan kegiatan yang dilakukan oleh guru dan murid. Guru bertindak sebagai pemberi informasi sedangkan murid bertindak sebagai penerima informasi, namun didalam pembelajaran tersebut tidak hanya guru yang bertindak sebagai pemeran utama melainkan siswa jug dilibatkan aktif dalam pembelajaran (student centered).

Komponen penunjang dalam KBM banyak jenisnya. Beberapa komponen yang harus terpenuhi antara lain harus adanya pendidik, peserta didik, bahan ajar, serta sarana dan prasarana (Kurniawan \& Masjudin, 2018; Nurdyansyah, 2018; Sugianto Efendhi, 2014; Yoan Agustina, 2015). Fasilitas sekolah dapat dikelompokkan menjadi sarana pendidikan dan prasarana pendidikan. semua perangkat, peralatan, bahan dan perabot yang secara lansung digunakan dalam proses pendidikan di sekolah termasuk dalam sarana pendidikan. Sedangkan prasarana pendidikan adalah semua perangkat kelengkapan dasar yang secara tidak lansung menunjang pelaksanaan proses pendidikan di sekolah. Beberapa sarana dan prasarana yang disebutkan di atas dapat menunjang kegiatan pembelajaran seperti adanya siswa, guru, ruang kelas, perpustakaan, UKS, Laboratorium bahasa/komputer, alat peraga, media pembelajaran, alat pelajaran, bahan 
pelajaran, perabot belajar, tempat olahraga, kantin, tempat bermain, kantor/ruang guru, WC/kamar mandi, tempat ibadah (Baharudin dan Esa Nur Wahyuni, 2008).

Bahan ajar merupakan bagian dari sarana pendidikan yang meliputi perangkat, bahan penunjang yang secara lansung digunakan dalam pembelajaran di kelas. Bahan ajar terdiri dari beberapa jenis seperti Silabus, RPP, Lembar Evaluasi/ LKS, Buku ajar, dan Instrumen penilaian. Buku ajar merupakan salah satu bagian dari bahan ajar yang tidak bisa terlepas dari guru dan siswa. Konten buku ajar yang dimiliki siswa merupakan penjabaran dari kurikulum yang dipakai dalam dunia pendidikan yaitu kurikulum 2013 (Kurtilas). Buku ajar pada kurikulum ini berbeda dengan kurikulum-kurikulum sebelumnya karena terdapat dua jenis buku yang tersedia yaitu buku guru dan buku siswa. Buku guru berisi tentang panduan mengajar, sedangkan buku siswa bukan berisi bacaan melainkan berbasis pada aktifitas berisi soal-soal yang menenkankan pada keterampilan proses (Suwandayani et al., 2016; Utami \& Suwandayani, 2018). Widodo dan Jasmadi (2008) menyatakan bahwa bahan ajar adalah seperangkat sarana atau alat pembelajaran yang berisikan materi pembelajaran, metode, dalam rangka mencapai tujuan yang diharapkan, yaitu mencapai kompetensi atau subkompetensi dengan segala kompleksitas.

Kelebihan dari penggunaan kurikulum 2013 banyak dan beragam, namun ada juga kekurangan dari pengimplementasiaan kurikulum ini (Suwandayani, 2018). Salah satu kekurangan yang banyak dikeluhkan oleh siswa dan wali murid terletak pada buku ajar yang digunakan (Octaviani, 2017). Konsep kurikulum 2013 memang kemampuan softskill dan hardskill siswa dibuat dengan komposisi seimbang, namun kenyataan di lapangan banyak yang mengeluhkan dengan komposisi bacaan dan soal-soal yang ada. Hanya sedikit sekali bacaan/penjelasan pada setiap topik pembahasan sedangkan soalsoal latihan yang tersedia cukup banyak, sehingga penguasaan konsep yang dikuasai siswa pun minim. Berdasarkan hasil pengamatan sebagian besar siswa tidak mampu menjawab soal pada buku siswa karena mereka belum mengusai konsep materi yang sedang mereka pelajari. Konsep yang belum matang namun soal-soal latihan begitu banyak sehingga ada banyak siswa yang nilainya belum sesuai dengan standar minimal ketuntasan belajar.

Berdasarkan hasil pengamatan penerapan buku ajar pada mata pelajaran IPA materi "Keragaman Suku Bangsa dan Budaya" tidak lebih dari $25 \%$ berisi bacaan sedangkan sisanya sekitar $75 \%$ berisi soal-soal evaluasi. Siswa kelas IV masih awam dengan keragaman budaya di Indonesia Misalnya mereka belum mampu menjawab dengan sempurna nama-nama tarian, lagu daerah, pakaian tradisonal, senjata daerah yang dimiliki oleh berbagai provinsi di Indonesia. Minimnya konsep/pengetahuan yang mereka miliki hal ini berimbas pada minimnya hasil tes belajar yang didapatkan siswa. Sejalan dengan penelitian (Kuncahyono, 2018) yang menyatakan bahwa penggunaan bahan ajar digital juga dapat menfasilitasi siswa dalam belajarnya baik secara mandiri maupun konvensional karena bahan ajar tersebut dilengkapi petunjuk untuk belajar mandiri, sehingga siswa dapat belajar sesuai dengan kemampuannya.

Berdasarkan beberapa alasan dan pengamatan yang telah dilakukan, peneliti tertarik untuk mengembangkan buku yang sudah ada dengan mambahkan informasi/penjelasan pada topik di atas dengan berpedoman pada kurikulum 2013 buku guru dan buku siswa dengan judul "Pengembangan Buku Ajar IPA SD Melalui Pendekatan Konsep Sebagai Wujud Cinta Keberagaman Suku Bangsa dan Budaya di Indonesia". Tujuan dari pengembangan ini adalah untuk membantu siswa dalam memahami konsep materi yang sedang dipelajari agar siswa tidak hanya menguasai keterampilan softskill tetapi juga hardskill. 


\section{METODE}

Jenis penelitian ini menggunakan metode penelitian dan pengembangan model 4D (Four D Model) yang terdiri dari tahap (1) Define (Pendefinisian), (2) Design (Perancangan), (3) Development (Pengembangan), (4) Disseminate (Penyebarluasan).

1. Tahap Pendefinisian (Define). Langkah-langkah pada tahap ini meliputi analisis akar masalah, analisis siswa, analisis materi pelajaran, analisis konsep, dan perumusan tujuan pembelajaran (Trianto, 2010). (a) analisis akar masalah untuk mengetahui masalah yang muncul dan dialami oleh peserta didik. (b) analisis siswa adalah para siswa kelas IV SDN Banyu urip IX Surabaya. (c) analisis materi pelajaran, buku ajar yang dikembangkan materi keragaman suku budaya dan bangsa pada pelajaran Ilmu Pengetahuan Alam yang berpedoman pada KI dan KD pada kurikulum 2013. (d) analisis konsep bertujuan untuk memberikan solusi terbaik atas masalah yang dialami siswa dengan memetakkan materi dan sub pokok bahasan melalui peta konsep. (e) Perumusan tujuan pembelajaran dilakukan sebanyak 2 kali dalam 1 minggu. Setiap pertemuan dilakukan selama 2 jam pelajaran, estimasi waktu untuk 1 jam pelajaran berlansung selama \pm 45 menit.

\section{Tahap Perencanaan (Design)}

Tahap perencanaan mulai dipersiapkan prototype buku ajar yang akan dikembangkan. Tahap ini meliputi, (a) Analisis Materi antara lain menyiapkan kurikulum 2013, analisis kompetensi inti dan kompetensi dasar, analisis materi pada buku siswa dan mencocokkan dengan materi yang ada di buku guru, mengidentifikasi ketidakcocokan antara materi dengan KI dan KD, membuat catatan kaki terhadap hasil analisis yang telah dilakukan. (b) Perencanaan Pengembangan Buku Ajar meliputi Memetakkan KI, KD berpedoman pada kurikulum 2013, Mencocokkan materi dan sub-sub materi yang akan dikembangkan dengan KI dan KD melalui peta konsep, Memetakkan materi dan sub-sub materi kedalam daftar isi sebagai acuan utama dalam mengembangkan materi yang akan dikembangkan kedalam buku ajar, Mencari minimal 3 buku yang dapat dijadikan sebagai bahan referensi dalam pengembangan buku ajar, Penyusunan draft awal dan desain buku ajar, Uji coba produk atau uji terbatas, Revisi dan perbaikan, Uji coba terbatas dan uji coba luas kepda siswa. (c) Penerapan Penggunaan Buku Ajar, Setiap siswa diberikan buku ajar IPA yang telah dirancang dan dikembangkan, guru menginstruksikan kepada siswa untuk membuka materi yang telah ditentukan, guru menginstruksikan kepada siswa untuk membaca dengan seksama untuk memahami materi yang sedang mereka baca, guru memberikan pertanyaan tanya jawab seputar materi yang sudah mereka baca, guru menginstruksikan kepada siswa untuk mengerjakan lembar evaluasi yang sudah tersedia dibuku, guru bersama siswa membahas lembar evaluasi yang telah dikerjakan siswa. (d) Validasi Ahli

Validasi akan dilakukan oleh beberapa validator yang kompeten dalam bidang penelitian yang dikembangkan. Komponen yang akan divalidasi yaitu penilaian buku ajar dari segi kelayakan isi, bahasa dan kegrafikan. Pengujian dilakukan oleh guru dan ahli dalam hal ini adalah dosen yang kompeten dalam bidang sains dan ke PGSD an. (1) Validasi pada evaluasi isi bertujuan untuk mengevaluasi isi buku ajar dan isi materi; (2) validasi pada evaluasi bahasa bertujuan untuk mengevaluasi bahasa yang digunakan dalam penyampaian materi, keruntutan, dan kesesuaian materi buku ajar; (3) validasi egrafikan bertujuan untuk mengevaluasi kualitas fisik buku ajar, ukuran buku, dan desain isi buku. 


\section{Tahap Pengembangan (Development)}

Tahap pengembangan merupakan rancangan-rancangan pada tahap sebelumnya yang akan direalisasikan. Pada tahap ini terdiri dari 2 langkah antara lain (a) penilaian ahli (expert appraisal)

Penilaian ahli diperlukankan peneliti pada produk yang akan dikembangkan dengan tujuan untuk memeroleh saran dan masukan terkait produk yang sedang dikembangkan pada draf I. saran dan komentar validator akan digunakan untuk memperbaiki produk pada draf II. (b) uji coba pengembangan (developmental testing) untuk mengetahui kelayakan dari buku ajar yang dikembangkan dari segi isi, bahasa maupun kegrafikan pada siswa kelas IV SD.

\section{Tahap Penyebarluasan (Disseminate)}

Tahap penyebarluasan merupakan langkah akhir dari pengembangan buku ajar. Tahap ini terdiri dari: validation testing, packaging, diffusion and adaption. Teknik pengumpulan data menggunakan dokumentasi, wawancara, angket. Sedangkan teknik analisis data menggunakan (1) data dokumentasi (2) data wawancara, dan (3) data angket. Angket penilaian responden disusun dengan menggunakan skala likert dengan rumus sebagai berikut.

$$
\mathrm{P}=\frac{\mathrm{f}}{\mathrm{N}} \mathrm{X} 100 \%
$$

Keterangan : $\mathrm{P}=$ Presentase

$\mathrm{F}=$ Jumlah Skor Validasi

$\mathrm{N}=$ Jumlah Seluruh Responden

Berikut adalah tabel ketetapan kriteria tingkat ketercapaian.

Tabel 1. Kriteria Tingkat Ketercapaian

\begin{tabular}{ccc}
\hline Tingkat ketercapaian & Kategori & Keterangan \\
$90 \%-100 \%$ & Sangat Baik & Tidak Perlu Direvisi \\
$75 \%-89 \%$ & Baik & Tidak Perlu Direvisi \\
$65 \%-74 \%$ & Cukup & Direvisi \\
$55 \%-64 \%$ & Kurang & Direvisi \\
$0-54 \%$ & Kurang Sekali & Direvisi \\
\hline
\end{tabular}

\section{HASIL DAN PEMBAHASAN}

Uji kelayakan buku ajar dilakukan oleh tiga validator antara lain 1 validator yang berasal dari guru SD dan 2 orang dosen PGSD. Uji kelayakan isi melibatkan validator wali kelas IV dengan alasan lebih memahami materi yang diajarkan di kelas IV. Dosen PGSD bidang keahlian komputer yang memahami tentang desain buku dilibatkan dalam uji kegrafikan. Uji bahasa melibatkan validator dosen PGSD bidang keahlian bahasa dan sastra indonesia yang memahami tentang tata bahasa baku/ non baku serta tingkatan bahasa untuk anak SD.

Tabel 2. Indikator Kelayakan Isi Pada Buku Ajar

\begin{tabular}{|c|c|c|c|c|c|c|}
\hline No & Sub Komponen & Butir Penilaian & Validator & Skor & $\%$ & Keterangan \\
\hline 1 & \multicolumn{6}{|l|}{ Kelayakan Isi } \\
\hline & Kesesuaian & 1. keluasan materi & 1 & 3 & & \\
\hline & materi dengan $\mathrm{KI}$ dan & & 2 & 4 & 83,33 & Baik \\
\hline & KD & & 3 & 3 & & \\
\hline
\end{tabular}


40 JP2SD (Jurnal Pemikiran dan Pengembangan Sekolah Dasar), Vol. 8 , No 1, April 2020 hlm 35-50 http://ejournal.umm.ac.id/index.php/jp2sd

\begin{tabular}{|c|c|c|c|c|c|c|}
\hline \multirow[t]{7}{*}{ No } & Sub Komponen & Butir Penilaian & Validator & Skor & $\%$ & Keterangan \\
\hline & & 2. kedalaman & 1 & 3 & \multirow{3}{*}{75} & \multirow{3}{*}{ Baik } \\
\hline & & materi & 2 & 3 & & \\
\hline & & \multirow{4}{*}{ 3. pilihan tema } & 3 & 3 & & \\
\hline & & & 1 & 3 & \multirow{3}{*}{83,33} & \multirow{3}{*}{ Baik } \\
\hline & & & 2 & 4 & & \\
\hline & & & 3 & 3 & & \\
\hline & Keakuratan materi & 4. keakuratan fakta & 1 & 4 & \multirow{3}{*}{83,33} & \multirow{3}{*}{ Baik } \\
\hline & & dan konsep & 2 & 3 & & \\
\hline & & \multirow{4}{*}{$\begin{array}{l}\text { 5. keakuratan } \\
\text { ilustrasi }\end{array}$} & 3 & 3 & & \\
\hline & & & 1 & 3 & \multirow{3}{*}{83,33} & \multirow{3}{*}{ Baik } \\
\hline & & & 2 & 3 & & \\
\hline & & & 3 & 4 & & \\
\hline & Materi pendukung & 6. kesesuaian dengan & 1 & 3 & \multirow{3}{*}{66,67} & \multirow{3}{*}{ Cukup } \\
\hline & \multirow[t]{5}{*}{ pembelajaran } & perkembangan & 2 & 3 & & \\
\hline & & ilmu & 3 & 2 & & \\
\hline & & \multirow[t]{3}{*}{ 7. konstektual } & 1 & 3 & & \multirow{3}{*}{ Baik } \\
\hline & & & 2 & 3 & \multirow[t]{2}{*}{75} & \\
\hline & & & 3 & 3 & & \\
\hline 2 & Kelayakan Penyajian & & & & & \\
\hline & Teknik penyajian & 8. keruntutan konsep & 1 & 4 & 91,67 & Sangat baik \\
\hline & & & 2 & 3 & & \\
\hline & & & 3 & 4 & & $\mathrm{Sa}$ \\
\hline & & 9. kekonsistenan & 1 & 3 & 91,67 & ngat baik \\
\hline & & sistematika & 2 & 4 & & \\
\hline & & & 3 & 4 & & \\
\hline & & 10. keseimbangan & 1 & 3 & & \\
\hline & & antar bab & 2 & 3 & 83,33 & Baik \\
\hline & & & 3 & 4 & & \\
\hline & Penyajian pembelajaran & 11. berpusat pada & 1 & 3 & & \\
\hline & & peserta didik & 2 & 3 & 75 & Baik \\
\hline & & & 3 & 3 & & \\
\hline & & 12.keakuratan & 1 & 3 & & \\
\hline & & ilustrasi & 2 & 4 & 75 & Baik \\
\hline & & & 3 & 2 & & \\
\hline & & 13. vaariasi penyajian & 1 & 4 & & \\
\hline & & & 2 & 4 & 91,67 & Sangat baik \\
\hline & & & 3 & 3 & & \\
\hline & Kelengkapan penyajian & 14. kata pengantar & 1 & 3 & 75 & Baik \\
\hline & & & 2 & 3 & & \\
\hline & & & 3 & 3 & & \\
\hline & & 15. daftar isi & 1 & 4 & 83,33 & Baik \\
\hline & & & 2 & 3 & & \\
\hline & & & 3 & 3 & & \\
\hline & & 16. daftar pustaka & 1 & 3 & 66,67 & Cukup \\
\hline & & & 2 & 2 & & \\
\hline & & & 3 & 3 & & \\
\hline & & 17. evaluasi & 1 & 3 & 91,67 & Sangat baik \\
\hline & & & 2 & 4 & & \\
\hline & & & 3 & 4 & & \\
\hline & & 18. proporsi gambar & 1 & 3 & 75 & Baik \\
\hline & & dan teks yang & 2 & 3 & & \\
\hline & & tepat & 3 & 3 & & \\
\hline & & 19. ilustrasi yang & 1 & 3 & 75 & Baik \\
\hline & & mendukung & 2 & 3 & & \\
\hline & & pesan & 3 & 3 & & \\
\hline
\end{tabular}


41 JP2SD (Jurnal Pemikiran dan Pengembangan Sekolah Dasar), Vol. 8, No 1, April 2020 hlm 35-50 http://ejournal.umm.ac.id/index.php/jp2sd

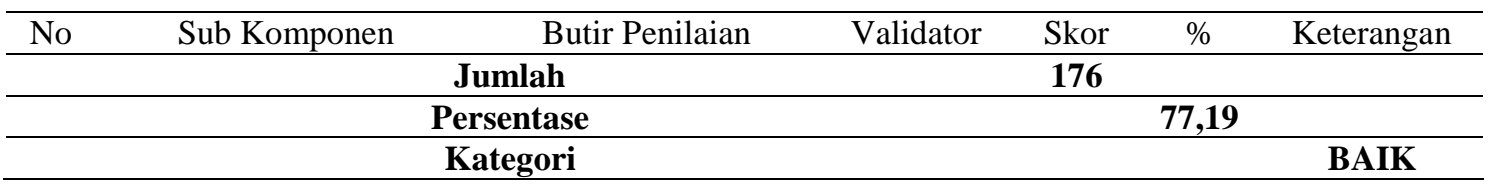

Berdasarkan hasil validasi yang dilakukan oleh 3 validator ada beberapa aspek yang menunjukkan nilai $\leq 75$ dengan kategori cukup sehingga perlu dilakukan evaluasi ulang namun tidak perlu dilakukan revisi. Jumlah skor yang diperoleh pada uji kelayakan isi sebasar 176 presentase rata-rata sebesar 77,19 \% dengan kategori baik, sehingga tidak perlu dilakukan revisi pada isi buku ajar. Saran dan masukan dari para validator adalah hindari penggunaan referensi lebih dari 10 tahun terakhir. Materi harus Up to date mengikuti dengan perkembangan yang ada, ada beberapa sumber yang belum dimasukkan kedalam daftar pustaka.

Tabel 3. Indikator Kelayakan Bahasa Pada Buku Ajar

\begin{tabular}{|c|c|c|c|c|c|c|}
\hline No & Sub Komponen & Butir Penilaian & Validator & Skor & $\%$ & Keterangan \\
\hline \multirow[t]{22}{*}{1} & \multicolumn{6}{|l|}{ Kelayakan Bahasa } \\
\hline & \multirow{9}{*}{$\begin{array}{l}\text { Kesesuaian dengan } \\
\text { tingkat perkembangan } \\
\text { siswa }\end{array}$} & 1. keluasan materi & 1 & 4 & & \\
\hline & & & 2 & 4 & 91,67 & Sangat baik \\
\hline & & & 3 & 3 & & \\
\hline & & 2. kedalaman & 1 & 3 & 83,33 & Baik \\
\hline & & materi & 2 & 4 & & \\
\hline & & & 3 & 3 & & \\
\hline & & 3. pilihan tema & 1 & 3 & 75 & Baik \\
\hline & & & 2 & 3 & & \\
\hline & & & 3 & 3 & & \\
\hline & \multirow[t]{6}{*}{ Komunikatif } & 4. keakuratan & 1 & 4 & 83,33 & Baik \\
\hline & & fakta dan & 2 & 3 & & \\
\hline & & konsep & 3 & 3 & & \\
\hline & & 5. keakuratan & 1 & 3 & 75 & Baik \\
\hline & & ilustrasi & 2 & 3 & & \\
\hline & & & 3 & 3 & & \\
\hline & \multirow{6}{*}{ Runtutan dan kesatuan } & 6. kesesuaian & 1 & 4 & 91,67 & Sangat baik \\
\hline & & dengan & 2 & 4 & & \\
\hline & & $\begin{array}{l}\text { perkembangan } \\
\text { ilmu }\end{array}$ & 3 & 3 & & \\
\hline & & 7. konstektual & 1 & 3 & 75 & Baik \\
\hline & & & 2 & 3 & & \\
\hline & & & 3 & 3 & & \\
\hline \multirow[t]{19}{*}{2} & \multicolumn{6}{|l|}{ Kelayakan Penyajian } \\
\hline & \multirow[t]{9}{*}{ Teknik penyajian } & 8. keruntutan & 1 & 4 & 91,67 & Sangat baik \\
\hline & & kosep & 2 & 3 & & \\
\hline & & & 3 & 4 & & \\
\hline & & 9. kekonsistenan & 1 & 4 & 91,67 & Sangat baik \\
\hline & & sistematika & 2 & 4 & & \\
\hline & & & 3 & 3 & & \\
\hline & & 10. keseimbangan & 1 & 4 & 91,67 & Sangat baik \\
\hline & & antar bab & 2 & 4 & & \\
\hline & & & 3 & 3 & & \\
\hline & \multirow[t]{9}{*}{ Penyajian pembelajaran } & 11. berpusat pada & 1 & 3 & 83,33 & Baik \\
\hline & & peserta didik & 2 & 3 & & \\
\hline & & & 3 & 4 & & \\
\hline & & 12.keakuratan & 1 & 3 & 83,33 & Baik \\
\hline & & ilustrasi & 2 & 3 & & \\
\hline & & & 3 & 4 & & \\
\hline & & 13. vaariasi & 1 & 2 & 66,67 & Cukup \\
\hline & & penyajian & 2 & 3 & & \\
\hline & & & 3 & 3 & & \\
\hline
\end{tabular}


42 JP2SD (Jurnal Pemikiran dan Pengembangan Sekolah Dasar), Vol. 8, No 1, April 2020 hlm 35-50 http://ejournal.umm.ac.id/index.php/jp2sd

\begin{tabular}{|c|c|c|c|c|c|c|}
\hline No & Sub Komponen & Butir Penilaian & Validator & Skor & $\%$ & Keterangan \\
\hline \multirow{19}{*}{\multicolumn{2}{|c|}{ Kelengkapan penyajian }} & 14. kata pengantar & 1 & 2 & 66,67 & Cukup \\
\hline & & & 2 & 3 & & \\
\hline & & & 3 & 3 & & \\
\hline & & 15. daftar isi & 1 & 4 & 83,33 & Baik \\
\hline & & & 2 & 3 & & \\
\hline & & & 3 & 3 & & \\
\hline & & 16. daftar pustaka & 1 & 2 & 66,67 & Cukup \\
\hline & & & 2 & 3 & & \\
\hline & & & 3 & 3 & & \\
\hline & & 17. evaluasi & 1 & 3 & 83,33 & Baik \\
\hline & & & 2 & 4 & & \\
\hline & & & 3 & 3 & & \\
\hline & & 18. proporsi & 1 & 3 & 91,67 & Sangat baik \\
\hline & & gambar dan & 2 & 4 & & \\
\hline & & teks yang & 3 & 4 & & \\
\hline & & 1 & & & & \\
\hline & & 19. ilustrasi yang & 1 & 3 & 66,67 & Cukup \\
\hline & & mendukung & 2 & 2 & & \\
\hline & & pesan & 3 & 3 & & \\
\hline \multicolumn{3}{|c|}{ Jumlah } & & 179 & & \\
\hline \multirow{2}{*}{\multicolumn{3}{|c|}{$\begin{array}{c}\text { Persentase } \\
\text { Kategori }\end{array}$}} & & & 78,50 & \\
\hline & & & & & & BAIK \\
\hline
\end{tabular}

Berdasarkan hasil validasi yang dilakukan oleh 3 validator ada 4 aspek yang menunjukkan nilai $\geq 66,67$ dengan kategori cukup tetapi memerlukan revisi, sehingga perlu dilakukan evaluasi dan perbaikan pada poin-poin indikator tersebut. Namun, berdasarkan data uji kelayakan bahassa pada tabel di atas secara keseluruhan menunjukkan presentase rata-rata sebesar 78,50 \% dengan jumlah skor sebasar 179 dengan kategori baik, sehingga secara umum tidak perlu dilakukan revisi pada aspek kelayakan bahasa pada buku ajar, hanya perlu merevisi beberapa indikator yang masih kurang. Beberapa saran dan komentar dari validator antara lain ucapan terimakasih yang terdapat pada kata pengantar tidak menggunakan gelar jika menggunakan kata sapaan ibu/bapak. Variasi dalam penyajian bahasa lebih menarik tidak monoton, penulisan daftar pustaka yang tidak sesuai dengan kaidah EYD, serta penggunaan ilustrasi kurang menarik.

Tabel 4. Indikator Kelayakan Kegrafikan Pada Buku Ajar

\begin{tabular}{|c|c|c|c|c|c|c|}
\hline No & Sub Komponen & Butir Penilaian & Validator & Skor & $\%$ & Keterangan \\
\hline \multirow[t]{10}{*}{1} & Ukuran Buku & & & & & \\
\hline & Ukuran & 1. Kesesuaian ukuran & 1 & 3 & 91,67 & Sangat baik \\
\hline & & buku dengan & 2 & 4 & & \\
\hline & & standar ISO A5 & 3 & 4 & & \\
\hline & & $(148 \mathrm{~mm} \times 210$ & & & & \\
\hline & & $\mathrm{mm})$ atau (176 & & & & \\
\hline & & $\mathrm{mm} \times 250 \mathrm{~mm})$ & & & & \\
\hline & & 2. Kesesuaian ukuran & 1 & 4 & 83,33 & Baik \\
\hline & & buku deengan & 2 & 3 & & \\
\hline & & materi isi buku & 3 & 3 & & \\
\hline \multirow[t]{6}{*}{2} & Desain Kulit Buku & & & & & \\
\hline & Tata Letak & 3. Penampilan unsur & 1 & 4 & 91,67 & Sangat baik \\
\hline & & tata letak pada kulit & 2 & 3 & & \\
\hline & & muka, belakang, dan & 3 & 4 & & \\
\hline & & $\begin{array}{l}\text { punggung memiliki } \\
\text { kesatuan (unity) }\end{array}$ & & & & \\
\hline & & & 1 & 4 & 91,67 & Sangat baik \\
\hline
\end{tabular}




\begin{tabular}{|c|c|c|c|c|c|c|}
\hline No & Sub Komponen & Butir Penilaian & Validator & Skor & $\%$ & Keterangan \\
\hline & & 4. Tampilan tata letak & 2 & 4 & & \\
\hline & & unsur muka, & 3 & 3 & & \\
\hline & & punggung, dan & & & & \\
\hline & & belakang sesuai atau & & & & \\
\hline & & $\begin{array}{l}\text { harmonis dan } \\
\text { memberikan kesan }\end{array}$ & & & & \\
\hline & & irama yang baik. & 1 & 3 & 91,67 & Sangat baik \\
\hline & & 5. menampilkan pusat & 2 & 4 & & \\
\hline & & pandang (point & 3 & 4 & & \\
\hline & & center) yang baik & 1 & 3 & 75 & Baik \\
\hline & & 6. kombinasi unsur & 2 & 3 & & \\
\hline & & tata letak (judul, & 3 & 3 & & \\
\hline & & $\begin{array}{l}\text { pengarang, ilustrasi, } \\
\text { dan logo) }\end{array}$ & 1 & 4 & 91,67 & Sangat baik \\
\hline & & 7. ukuran unsur tata & 2 & 3 & & \\
\hline & & letak proporsional & 3 & 4 & & \\
\hline & & dengan ukuran buku & 1 & 4 & 91,67 & Sangat baik \\
\hline & & 8. warna unsur tata & 2 & 4 & & \\
\hline & & letak harmonis dan & 3 & 3 & & \\
\hline & & memperjaelas fungsi & & & & \\
\hline & & (materi isi buku) & 1 & 2 & 66,67 & Cukup \\
\hline & & 9. menampilkan & 2 & 3 & & \\
\hline & & kekontrasan yang & 3 & 3 & & \\
\hline & & baik & 1 & 3 & 66,67 & Cukup \\
\hline & & 10. penampilan unsur & 2 & 3 & & \\
\hline & & $\begin{array}{l}\text { tata letak konsisten } \\
\text { (sesuai pola) }\end{array}$ & 3 & 2 & & \\
\hline 3 & Tifografi & & & & & \\
\hline & Huruf Yang Digunakan & 11. ukuran huruf judul & 1 & 4 & 91,67 & Sangat baik \\
\hline & Menarik Dan Mudah & buku lebih & 2 & 3 & & \\
\hline & Dibaca & dominan & 3 & 4 & & \\
\hline & & dibandingkan & & & & \\
\hline & & $\begin{array}{l}\text { (nama pengarang } \\
\text { dan penerbit) }\end{array}$ & & & & \\
\hline & & 12. warna judul buku & 1 & 3 & 91,67 & Sangat baik \\
\hline & & kontras dengan & 2 & 4 & & \\
\hline & & warna latar & 3 & 4 & & \\
\hline & & belakang & & & & \\
\hline & & 13. ukuran huruf & & & & \\
\hline & & proporsional & 1 & 3 & 75 & Baik \\
\hline & & dibandingkan & 2 & 3 & & \\
\hline & & dengan ukuran & 3 & 3 & & \\
\hline & & buku & & & & \\
\hline & Huruf Yang Sederhana & 14. tidak terlalu & 1 & 4 & 91,67 & Sangat baik \\
\hline & & banyak kombinasi & 2 & 3 & & \\
\hline & & jenis huruf & 3 & 4 & & \\
\hline & & 15. tidak & 1 & 4 & 91,67 & Sangat baik \\
\hline & & menggunakan huruf & 2 & 4 & & \\
\hline & & hias atau dekorasi & 3 & 3 & & \\
\hline & & 16. Sesuai dengan & 1 & 4 & 91,67 & Sangat baik \\
\hline & & jenis huruf untuk & 2 & 3 & & \\
\hline & & isi/materi buku & 3 & 4 & & \\
\hline 4 & Ilustrasi & & & & & \\
\hline & Mencerminkan & 17. ilustrasi dapat & 1 & 3 & 83,33 & Baik \\
\hline & Buku & menggambarkan & 2 & 4 & & \\
\hline & & isi/ materi buku & 3 & 3 & & \\
\hline & & & 1 & 3 & 75 & Baik \\
\hline
\end{tabular}




\begin{tabular}{|c|c|c|c|c|c|c|}
\hline No & Sub Komponen & Butir Penilaian & Validator & Skor & $\%$ & Keterangan \\
\hline & & 18. ilutrasi mampu & 2 & 3 & & \\
\hline & & mengungkapkan & 3 & 3 & & \\
\hline & & karakter objek & 1 & 4 & 91,67 & Sangat baik \\
\hline & & 19. bentuk, warna, & 2 & 4 & & \\
\hline & & $\begin{array}{l}\text { ukuran proporsi } \\
\text { objek sesuai realita }\end{array}$ & 3 & 3 & & \\
\hline \multirow[t]{22}{*}{5} & \multicolumn{6}{|l|}{ Desain Isi Buku } \\
\hline & \multirow[t]{21}{*}{ Tata Letak Konsisten } & 20. penempatan tata & 1 & 3 & 83,33 & Baik \\
\hline & & letak konsisten & 2 & 4 & & \\
\hline & & berdasarkan pola & 3 & 3 & & \\
\hline & & 21. spasi antar & 1 & 3 & 83,33 & Sangat baik \\
\hline & & paragraf jelas & 2 & 3 & & \\
\hline & & & 3 & 4 & & \\
\hline & & 22. penempatan judul & 1 & 3 & 91,67 & Baik \\
\hline & & bab dan yang & 2 & 4 & & \\
\hline & & setara konsisten & 3 & 4 & & \\
\hline & & 23. bidang cetak dan & 1 & 3 & 83,33 & Sangat baik \\
\hline & & marjin & 2 & 3 & & \\
\hline & & proporsional & 3 & 4 & & \\
\hline & & 24. spasi antar teks & 1 & 3 & 91,67 & Sangat baik \\
\hline & & dan marjin sesuai & 2 & 4 & & \\
\hline & & & 3 & 4 & & \\
\hline & & 25. marjin antar dua & 1 & 4 & 91,67 & Baik \\
\hline & & halaman & 2 & 3 & & \\
\hline & & $\begin{array}{l}\text { berdampingan } \\
\text { proporsional }\end{array}$ & 3 & 4 & & \\
\hline & & 26. kesesuaian bentuk, & 1 & 3 & 75 & Baik \\
\hline & & dan ukran tata & 2 & 3 & & \\
\hline & & letak & 3 & 3 & & \\
\hline \multirow[t]{12}{*}{6} & Kelengkapan $\quad$ Unsur & 27. judul bab & 1 & 4 & 91,67 & Sangat baik \\
\hline & \multirow[t]{11}{*}{ Tata Letak Buku } & & 2 & 4 & & \\
\hline & & & 3 & 3 & & \\
\hline & & 28. sub judul bab & 1 & 3 & 75 & Baik \\
\hline & & & 2 & 3 & & \\
\hline & & & 3 & 3 & & \\
\hline & & 29. angka halaman & 1 & 4 & 91,67 & Sangat baik \\
\hline & & & 2 & 4 & & \\
\hline & & & 3 & 3 & & \\
\hline & & 30. Keteragan gambar & 1 & 4 & 91,67 & Sangat baik \\
\hline & & & 2 & 3 & & \\
\hline & & & 3 & 4 & & \\
\hline \multirow[t]{14}{*}{7} & \multirow[t]{14}{*}{ Tifografi } & 31. tidak & 1 & 4 & 91,67 & Sangat baik \\
\hline & & menggunakan & 2 & 3 & & \\
\hline & & $\begin{array}{l}\text { terlalu banyak } \\
\text { jenis huruf }\end{array}$ & 3 & 4 & & \\
\hline & & 32. spasi antar baris & 1 & 3 & 75 & Baik \\
\hline & & susunan teks & 2 & 3 & & \\
\hline & & normal & 3 & 3 & & \\
\hline & & 33. spasi antar huruf & 1 & 4 & 91,67 & Sangat baik \\
\hline & & normal & 2 & 3 & & \\
\hline & & & 3 & 4 & & \\
\hline & & 34. mampu & 1 & 3 & 66,67 & Cukup \\
\hline & & mengungkapkan & 2 & 2 & & \\
\hline & & $\begin{array}{l}\text { makna atau arti } \\
\text { dari objek }\end{array}$ & 3 & 3 & & \\
\hline & & 35. keseluruhan & 1 & 4 & 91,67 & Sangat baik \\
\hline & & illustrasi serasi & 2 & 4 & & \\
\hline
\end{tabular}


45 JP2SD (Jurnal Pemikiran dan Pengembangan Sekolah Dasar), Vol. 8, No 1, April 2020 hlm 35-50 http://ejournal.umm.ac.id/index.php/jp2sd

\begin{tabular}{|c|c|c|c|c|c|c|}
\hline No & Sub Komponen & Butir Penilaian & Validator & Skor & $\%$ & Keterangan \\
\hline & & & 3 & 3 & & \\
\hline & & Jumlah & & 359 & & \\
\hline & & rsentase & & & 85,4 & \\
\hline
\end{tabular}

Berdasarkan hasil validasi yang dilakukan oleh 3 validator ada 3 aspek yang menunjukkan nilai $\geq 66,67$ dengan kategori cukup tetapi memerlukan revisi, sehingga perlu dilakukan evaluasi dan perbaikan pada poin-poin indikator tersebut. Namun, berdasarkan data pada tabel di atas secara keseluruhan menunjukkan jumlah skor yang diperoleh pada uji kelayakan kegrafikan sebasar 359 dengan presentase rata-rata sebesar 85,47 \% dengan kategori baik, sehingga secara umum tidak perlu dilakukan revisi pada aspek kelayakan kegrafikan pada buku ajar, hanya perlu merevisi beberapa indikator yang masih kurang. Senada hasil penelitian Sebagaimana (Wibowo et al., 2019) bahwa pengembangan buku enterdal (ensiklopedia tematik sumber daya alam) berdasarkan penilaian persentase hasil validasi ahli media dan materi dengan kategori sangat layak.

Beberapa saran dan komentar dari validator antara lain. Warna yang ditampilkan tidak menunjukkan kekontrasan yang seimbang, pengaturan tata letak antar bab belum seragam, pada desain cover gambar belum mampu mengungkapkan makna atau arti dari judul. Berikut adalah penilaian angket siswa meliputi kelayakan isi, kelayakan bahasa, dan kelayakan kegrafikan.

\section{Tabel 5. Hasil Angket Siswa Pada Uji Coba Terbatas}

\begin{tabular}{|c|c|c|c|c|c|}
\hline No & Pertayaan & $\begin{array}{l}\text { Pilihan } \\
\text { Jawaban }\end{array}$ & $\begin{array}{c}\text { Jumlah } \\
\text { Siswa }\end{array}$ & $\%$ & Keterangan \\
\hline \multirow[t]{4}{*}{1} & \multirow[t]{4}{*}{ Tampilan buku ini menarik } & Sangat baik & 6 & \multirow{4}{*}{90} & Sangat baik \\
\hline & & Baik & 4 & & \\
\hline & & Cukup & 0 & & \\
\hline & & Kurang & 0 & & \\
\hline \multirow[t]{4}{*}{2} & \multirow{4}{*}{$\begin{array}{l}\text { Terdapat keserasian ukuran, warna, dan } \\
\text { tata letak pada sampul buku ini }\end{array}$} & Sangat baik & 4 & \multirow{4}{*}{77,5} & Baik \\
\hline & & Baik & 3 & & \\
\hline & & Cukup & 3 & & \\
\hline & & Kurang & 0 & & \\
\hline \multirow[t]{4}{*}{3} & \multirow{4}{*}{$\begin{array}{l}\text { Kerangka isi pada bagian awal bab } \\
\text { membantu memahami isi bacaan }\end{array}$} & Sangat baik & 6 & \multirow{4}{*}{90} & Sangat baik \\
\hline & & Baik & 4 & & \\
\hline & & Cukup & 0 & & \\
\hline & & Kurang & 0 & & \\
\hline \multirow[t]{4}{*}{4} & \multirow{4}{*}{$\begin{array}{l}\text { Memiliki kejelasan petunjuk pada tiap } \\
\text { awal bab }\end{array}$} & Sangat baik & 4 & \multirow{4}{*}{85} & Baik \\
\hline & & Baik & 4 & & \\
\hline & & Cukup & 2 & & \\
\hline & & Kurang & 1 & & \\
\hline \multirow[t]{4}{*}{5} & \multirow{4}{*}{$\begin{array}{l}\text { Ukuran dan jenis huruf yang digunakan } \\
\text { dalam buku teks ini mudah dibaca }\end{array}$} & Sangat baik & 7 & \multirow{4}{*}{92,5} & Sangat baik \\
\hline & & Baik & 3 & & \\
\hline & & Cukup & 0 & & \\
\hline & & Kurang & 0 & & \\
\hline \multirow[t]{4}{*}{6} & \multirow{4}{*}{$\begin{array}{l}\text { Kalimat dan paragraf yang digunakan } \\
\text { dalam buku ini jelas dan mudah dipahami }\end{array}$} & Sangat baik & 5 & \multirow{4}{*}{87,5} & Baik \\
\hline & & Baik & 5 & & \\
\hline & & Cukup & 0 & & \\
\hline & & Kurang & 0 & & \\
\hline \multirow[t]{4}{*}{7} & \multirow{4}{*}{$\begin{array}{l}\text { Bahasa yang digunakan sederhana dan } \\
\text { mudah dimengerti }\end{array}$} & Sangat baik & 4 & \multirow{4}{*}{85} & Baik \\
\hline & & Baik & 6 & & \\
\hline & & Cukup & 0 & & \\
\hline & & Kurang & 0 & & \\
\hline \multirow[t]{3}{*}{8} & \multirow[t]{3}{*}{ Gambar yang disajikan jelas } & Sangat baik & 8 & \multirow{3}{*}{95} & Sangat baik \\
\hline & & Baik & 2 & & \\
\hline & & Cukup & 0 & & \\
\hline
\end{tabular}


46 JP2SD (Jurnal Pemikiran dan Pengembangan Sekolah Dasar), Vol. 8, No 1, April 2020 hlm 35-50 http://ejournal.umm.ac.id/index.php/jp2sd

\begin{tabular}{|c|c|c|c|c|c|}
\hline No & Pertayaan & $\begin{array}{c}\text { Pilihan } \\
\text { Jawaban }\end{array}$ & $\begin{array}{l}\text { Jumlah } \\
\text { Siswa }\end{array}$ & $\%$ & Keterangan \\
\hline & & Kurang & 0 & & \\
\hline \multirow[t]{4}{*}{9} & \multirow{4}{*}{$\begin{array}{l}\text { Gambar yang disajikan sudah sesuai } \\
\text { (tidak terlalu bayak dan tidak terlalu } \\
\text { sedikit) }\end{array}$} & Sangat baik & 4 & & \multirow[t]{4}{*}{ Baik } \\
\hline & & Baik & 3 & 75 & \\
\hline & & Cukup & 2 & & \\
\hline & & Kurang & 1 & & \\
\hline \multirow[t]{4}{*}{10} & \multirow{4}{*}{$\begin{array}{l}\text { Adanya keterangan pada setiap gambar } \\
\text { yang disajikan pada buku ini }\end{array}$} & Sangat baik & 8 & & \multirow[t]{4}{*}{ Sangat baik } \\
\hline & & Baik & 2 & 95 & \\
\hline & & Cukup & 0 & & \\
\hline & & Kurang & 0 & & \\
\hline \multirow[t]{4}{*}{11} & \multirow[t]{4}{*}{ Gambar yang disajikan menarik } & Sangat baik & 9 & & \multirow[t]{4}{*}{ Sangat baik } \\
\hline & & Baik & 1 & 97,5 & \\
\hline & & Cukup & 0 & & \\
\hline & & Kurang & 0 & & \\
\hline \multirow[t]{4}{*}{12} & \multirow{4}{*}{$\begin{array}{l}\text { Gambar yang disajikan sesuai dengan } \\
\text { materi sehingga dapat dihami dengan } \\
\text { mudah }\end{array}$} & Sangat baik & 8 & & \multirow[t]{4}{*}{ Sangat baik } \\
\hline & & Baik & 2 & 95 & \\
\hline & & Cukup & 0 & & \\
\hline & & Kurang & 0 & & \\
\hline \multirow[t]{4}{*}{13} & \multirow{4}{*}{$\begin{array}{l}\text { Materi yang disajikan dalam buku ini } \\
\text { sudah runtut }\end{array}$} & Sangat baik & 5 & & \multirow[t]{4}{*}{ Baik } \\
\hline & & Baik & 5 & 87,5 & \\
\hline & & Cukup & 0 & & \\
\hline & & Kurang & 0 & & \\
\hline \multirow[t]{4}{*}{14} & \multirow{4}{*}{$\begin{array}{l}\text { Saya dapat mengikuti kegiatan belajar } \\
\text { tahap demi tahap dengan mudah }\end{array}$} & Sangat baik & 4 & & \multirow[t]{4}{*}{ Baik } \\
\hline & & Baik & 6 & 85 & \\
\hline & & Cukup & 0 & & \\
\hline & & Kurang & 0 & & \\
\hline 15 & Saya dapat dengan mudah memahami & Sangat baik & 4 & & Baik \\
\hline & kalimat yang digunakan dalam buku ini & Baik & 3 & 75 & \\
\hline & & Cukup & 2 & & \\
\hline & & Kurang & 1 & & \\
\hline 16 & Saya dapat memahami lambang atau & Sangat baik & 6 & & Baik \\
\hline & simbol yang digunakan pada buku ini & Baik & 3 & 87,5 & \\
\hline & & Cukup & 1 & & \\
\hline & & Kurang & 0 & & \\
\hline 17 & Saya dapat memahami istilah-istilah & Sangat baik & 3 & & Cukup \\
\hline & dalam buku ini & Baik & 3 & 72,5 & \\
\hline & & Cukup & 4 & & \\
\hline & & Kurang & 0 & & \\
\hline 18 & Materi dalam buku ini mendorong & Sangat baik & 5 & & Baik \\
\hline & keingintahuan saya & Baik & 5 & 87,5 & \\
\hline & & Cukup & 0 & & \\
\hline & & Kurang & 0 & & \\
\hline 19 & Latihan soal yang digunakan dalam buku & Sangat baik & 7 & & Sangat baik \\
\hline & ini sesuai dengan materi & Baik & 2 & 90 & \\
\hline & & Cukup & 1 & & \\
\hline & & Kurang & 0 & & \\
\hline 20 & Saya merasa lebih mudah belajar dengan & Sangat baik & 5 & & Baik \\
\hline & buku ini & Baik & 3 & 80 & \\
\hline & & Cukup & 1 & & \\
\hline & & Kurang & 1 & & \\
\hline 21 & Dengan buku ini saya dapat belajar lebih & Sangat baik & 5 & & Baik \\
\hline & terarah dan runtut & Baik & 5 & 87,5 & \\
\hline & & Cukup & 0 & & \\
\hline & & Kurang & 0 & & \\
\hline 22 & Saya lebih rajin belajar dengn & Sangat baik & 6 & & Sangat baik \\
\hline & menggunakan buku ini. & Baik & 4 & 95 & \\
\hline
\end{tabular}


47 JP2SD (Jurnal Pemikiran dan Pengembangan Sekolah Dasar), Vol. 8, No 1, April 2020 hlm 35-50 http://ejournal.umm.ac.id/index.php/jp2sd

\begin{tabular}{lcccc}
\hline \multirow{2}{*}{ No } & Pertayaan & Pilihan & Jumlah & \\
& & Jawaban & Siswa & Keterangan \\
\hline & Cukup & 1 & & \\
& Kurang & 0 & & \\
& & & $\mathbf{8 6 , 9}$ & Baik
\end{tabular}

Presentase rata-rata yang diperoleh sebesar 86,93\% dengan kategori baik dan tidak perlu adanya revisi ulang. setelah melalui uji coba terbatas, tahap selanjutnya adalah melakukan uji coba luas dengan siswa sejumlah 15 orang. Uji coba luas dimaksudkan untuk menguji kelayakan buku ajar dengan melibatkan siswa yang lebih banyak.

4. Uji Coba Luas

Berikut adalah penilaian yang diberikan siswa hasil pengisian angket pada uji coba luas. Tabel 6. Hasil Angket Siswa Pada Uji Coba Luas

\begin{tabular}{|c|c|c|c|c|c|}
\hline No & Pertayaan & $\begin{array}{c}\text { Pilihan } \\
\text { Jawaban }\end{array}$ & $\begin{array}{c}\text { Jumlah } \\
\text { Siswa }\end{array}$ & $\%$ & Keterangan \\
\hline \multirow[t]{4}{*}{1} & \multirow[t]{4}{*}{ Tampilan buku ini menarik } & Sangat baik & 9 & \multirow{4}{*}{80} & Baik \\
\hline & & Baik & 4 & & \\
\hline & & Cukup & 2 & & \\
\hline & & Kurang & 0 & & \\
\hline \multirow[t]{4}{*}{2} & \multirow{4}{*}{$\begin{array}{l}\text { Terdapat keserasian ukuran, warna, dan } \\
\text { tata letak pada sampul buku ini }\end{array}$} & Sangat baik & 7 & \multirow{4}{*}{88,33} & Baik \\
\hline & & Baik & 5 & & \\
\hline & & Cukup & 3 & & \\
\hline & & Kurang & 0 & & \\
\hline \multirow[t]{4}{*}{3} & \multirow{4}{*}{$\begin{array}{l}\text { Kerangka isi pada bagian awal bab } \\
\text { membantu memahami isi bacaan }\end{array}$} & Sangat baik & 7 & \multirow{4}{*}{90} & Sangat baik \\
\hline & & Baik & 6 & & \\
\hline & & Cukup & 2 & & \\
\hline & & Kurang & 0 & & \\
\hline \multirow[t]{4}{*}{4} & \multirow{4}{*}{$\begin{array}{l}\text { Memiliki kejelasan petunjuk pada tiap } \\
\text { awal bab }\end{array}$} & Sangat baik & 6 & \multirow{4}{*}{81,66} & Baik \\
\hline & & Baik & 6 & & \\
\hline & & Cukup & 3 & & \\
\hline & & Kurang & 1 & & \\
\hline \multirow[t]{4}{*}{5} & \multirow{4}{*}{$\begin{array}{l}\text { Ukuran dan jenis huruf yang digunakan } \\
\text { dalam buku teks ini mudah dibaca }\end{array}$} & Sangat baik & 8 & \multirow{4}{*}{88,33} & Baik \\
\hline & & Baik & 7 & & \\
\hline & & Cukup & 0 & & \\
\hline & & Kurang & 0 & & \\
\hline \multirow[t]{4}{*}{6} & \multirow{4}{*}{$\begin{array}{l}\text { Kalimat dan paragraf yang digunakan } \\
\text { dalam buku ini jelas dan mudah dipahami }\end{array}$} & Sangat baik & 7 & \multirow{4}{*}{86,66} & Baik \\
\hline & & Baik & 8 & & \\
\hline & & Cukup & 0 & & \\
\hline & & Kurang & 0 & & \\
\hline \multirow[t]{4}{*}{7} & \multirow{4}{*}{$\begin{array}{l}\text { Bahasa yang digunakan sederhana dan } \\
\text { mudah dimengerti }\end{array}$} & Sangat baik & 6 & \multirow{4}{*}{80} & Baik \\
\hline & & Baik & 9 & & \\
\hline & & Cukup & 0 & & \\
\hline & & Kurang & 0 & & \\
\hline \multirow[t]{4}{*}{8} & \multirow[t]{4}{*}{ Gambar yang disajikan jelas } & Sangat baik & 9 & \multirow{4}{*}{90} & Sangat baik \\
\hline & & Baik & 6 & & \\
\hline & & Cukup & 0 & & \\
\hline & & Kurang & 0 & & \\
\hline \multirow[t]{4}{*}{9} & \multirow{4}{*}{$\begin{array}{l}\text { Gambar yang disajikan sudah sesuai } \\
\text { (tidak terlalu bayak dan tidak terlalu } \\
\text { sedikit) }\end{array}$} & Sangat baik & 4 & & Cukup \\
\hline & & Baik & 6 & 71,66 & \\
\hline & & Cukup & 4 & & \\
\hline & & Kurang & 1 & & \\
\hline 10 & Adanya keterangan pada setiap gambar & Sangat baik & 10 & & Sangat baik \\
\hline & yang disajikan pada buku ini & Baik & 5 & 91,66 & \\
\hline & & Cukup & 0 & & \\
\hline & & Kurang & 0 & & \\
\hline
\end{tabular}


48 JP2SD (Jurnal Pemikiran dan Pengembangan Sekolah Dasar), Vol. 8, No 1, April 2020 hlm 35-50 http://ejournal.umm.ac.id/index.php/jp2sd

\begin{tabular}{|c|c|c|c|c|c|}
\hline No & Pertayaan & $\begin{array}{l}\text { Pilihan } \\
\text { Jawaban }\end{array}$ & $\begin{array}{c}\text { Jumlah } \\
\text { Siswa }\end{array}$ & $\%$ & Keterangan \\
\hline \multirow[t]{4}{*}{11} & \multirow[t]{4}{*}{ Gambar yang disajikan menarik } & Sangat baik & 9 & \multirow{4}{*}{88,33} & \multirow[t]{4}{*}{ Baik } \\
\hline & & Baik & 5 & & \\
\hline & & Cukup & 1 & & \\
\hline & & Kurang & 0 & & \\
\hline \multirow[t]{4}{*}{12} & \multirow{4}{*}{$\begin{array}{l}\text { Gambar yang disajikan sesuai dengan } \\
\text { materi sehingga dapat dihami dengan } \\
\text { mudah }\end{array}$} & Sangat baik & 9 & \multirow{4}{*}{88,33} & \multirow[t]{4}{*}{ Baik } \\
\hline & & Baik & 5 & & \\
\hline & & Cukup & 1 & & \\
\hline & & Kurang & 0 & & \\
\hline \multirow[t]{4}{*}{13} & \multirow{4}{*}{$\begin{array}{l}\text { Materi yang disajikan dalam buku ini } \\
\text { sudah runtut }\end{array}$} & Sangat baik & 7 & \multirow{4}{*}{86,66} & \multirow[t]{4}{*}{ Baik } \\
\hline & & Baik & 8 & & \\
\hline & & Cukup & 0 & & \\
\hline & & Kurang & 0 & & \\
\hline \multirow[t]{4}{*}{14} & \multirow{4}{*}{$\begin{array}{l}\text { Saya dapat mengikuti kegiatan belajar } \\
\text { tahap demi tahap dengan mudah }\end{array}$} & Sangat baik & 5 & \multirow{4}{*}{81,66} & \multirow[t]{4}{*}{ Baik } \\
\hline & & Baik & 9 & & \\
\hline & & Cukup & 1 & & \\
\hline & & Kurang & 0 & & \\
\hline \multirow[t]{4}{*}{15} & Saya dapat dengan mudah memahami & Sangat baik & 7 & \multirow{4}{*}{78,33} & \multirow[t]{4}{*}{ Baik } \\
\hline & \multirow[t]{3}{*}{ kalimat yang digunakan dalam buku ini } & Baik & 4 & & \\
\hline & & Cukup & 3 & & \\
\hline & & Kurang & 1 & & \\
\hline \multirow[t]{4}{*}{16} & Saya dapat memahami lambang atau & Sangat baik & 7 & & Baik \\
\hline & simbol yang digunakan pada buku ini & Baik & 6 & 83,33 & \\
\hline & & Cukup & 2 & & \\
\hline & & Kurang & 0 & & \\
\hline 17 & Saya dapat memahami istilah-istilah & Sangat baik & 6 & & Baik \\
\hline & dalam buku ini & Baik & 7 & 81,66 & \\
\hline & & Cukup & 2 & & \\
\hline & & Kurang & 0 & & \\
\hline 18 & Materi dalam buku ini mendorong & Sangat baik & 8 & & Baik \\
\hline & keingintahuan saya & Baik & 7 & 88,33 & \\
\hline & & Cukup & 0 & & \\
\hline & & Kurang & 0 & & \\
\hline 19 & Latihan soal yang digunakan dalam buku & Sangat baik & 7 & & Baik \\
\hline & ini sesuai dengan materi & Baik & 5 & 81,66 & \\
\hline & & Cukup & 3 & & \\
\hline & & Kurang & 0 & & \\
\hline 20 & Saya merasa lebih mudah belajar dengan & Sangat baik & 8 & & Baik \\
\hline & buku ini & Baik & 5 & 83,33 & \\
\hline & & Cukup & 1 & & \\
\hline & & Kurang & 1 & & \\
\hline 21 & Dengan buku ini saya dapat belajar lebih & Sangat baik & 8 & & \\
\hline & terarah dan runtut & Baik & 7 & 88,33 & Baik \\
\hline & & Cukup & 0 & & \\
\hline & & Kurang & 0 & & \\
\hline 22 & Saya lebih rajin belajar dengn & Sangat baik & 8 & & \\
\hline & menggunakan buku ini. & Baik & 6 & 86,6 & Baik \\
\hline & & Cukup & 1 & 6 & \\
\hline & & Kurang & 0 & & \\
\hline & Persentase rata-rata & & & $\mathbf{9 2 , 5 7}$ & Sangat baik \\
\hline
\end{tabular}

Presentase rata-rata yang diperoleh pada uji coba luas sebesar 92,57\%. Adanya kenaikan respon siswa sebesar 5,65 \% dari persentase semula 86,93\% menjadi $92,57 \%$ dengan kategori sangat baik sehingga tidak perlu adanya revisi ulang. 


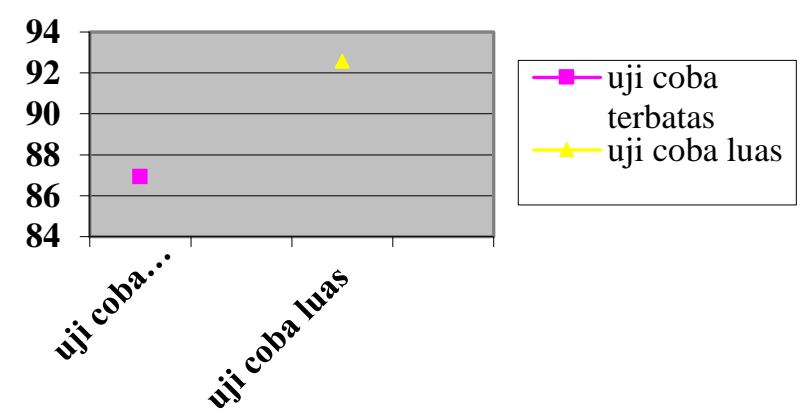

Grafik 1. Presentase Kenaikan Uji coba terbatas dan Uji coba Luas

Grafik di atas memaparkan kenaikan rata-rata dari uji coba terbatas dengan presentase rata-rata sebesar $86,93 \%$ dengan kategori baik, sedangkan pada uji coba luas dengan presentase rata-rata sebesar $92,57 \%$ dengan kategori sangat baik terjadi kenaikan sebesar $5,64 \%$.

\section{SIMPULAN}

Hasil analisis data penelitian dan pengembangan buku ajar IPA SD melalui pendekatan konsep dapat disimpulkan hal-hal sebagai berikut. (1) Proses pengembangan buku ajar IPA SD dikembangkan dari kurikulum 2013 menggunakan model 4D (Four D Model) yang terdiri dari tahap define, design develop, dan disseminate (2) kelayakan buku ajar IPA SD melalui uji validasi oleh 3 validator meliputi uji kelayakan isi, uji kelayakan Bahasa dan uji kelayakan kegrafikan. Pada aspek kelayakan isi, Bahasa, dan kegrafikan masing-masing mendapatkan hasil dengan kategori baik. Pada aspek keterbacaan dan keterpakaian buku ajar pada uji coba terbatas mendapatkan hasil dalam kategori baik, sedangkan pada uji coba luas mendapatkan hasil dalam kategori sangat baik.

\section{REFERENSI}

Baharuddin dan Esa Nur Wahyuni. 2008. Teori Belajar dan Pembelajaran. Yogyakarta: Ar-ruzz Media

Harjanto. (2008). Perencanaan Pembelajaran. Jakarta: Rineka Cipta.

Haryati, M. (2007). Model dan Teknik Penilaian Pada Satuan Pendidikan. Jakarta: Gaung Persada Press.

Kuncahyono, K. (2018). Pengembangan E-Modul (Modul Digital) dalam Pembelajaran Tematik Di Sekolah Dasar. JMIE (Journal of Madrasah Ibtidaiyah Education), 2(2), 219-231.

Kurniawan, A., \& Masjudin, M. (2018). Pengembangan buku ajar microteaching berbasis praktik untuk meningkatkan keterampilan mengajar calon guru.

Prosiding Seminar Nasional Pendidik Dan Pengembang Pendidikan Indonesia, 9-16.

Nurdyansyah, N. (2018). Pengembangan Bahan Ajar Modul Ilmu Pengetahuan Alambagi Siswa Kelas Iv Sekolah Dasar. Universitas Muhammadiyah Sidoarjo.

Octaviani, S. (2017). Pengembangan bahan ajar tematik dalam implementasi kurikulum 2013 kelas 1 sekolah dasar. EduHumaniora| Jurnal Pendidikan Dasar Kampus Cibiru, 9(2), 93-98. 
Sugianto Efendhi, E. (2014). Pengembangan Bahan Ajar Buku Berjendela Sebagai Pendukung Implementasi Pembelajaran Berbasis Scientific Approach Pada Materi Jurnal Khusus. Jurnal Pendidikan Akuntansi (JPAK), 2(2).

Suwandayani, B. I. (2018). Analisis Perencanaan Pembelajaran Tematik Pada Kurikulum 2013 di SD Negeri Kauman I Malang. ELSE (Elementary School Education Journal): Jurnal Pendidikan Dan Pembelajaran Sekolah Dasar, 2(1), 78-88.

Suwandayani, B. I., Akbar, S., \& Hanurawan, F. (2016). Model Pembelajaran Pendidikan Karakter Kelas I di SD Negeri Kauman I Kota Malang. Jurnal Pendidikan: Teori, Penelitian Dan Pengembangan, 1(10), 1981-1986.

Utami, I. W. P., \& Suwandayani, B. I. (2018). Perencanaan Pembelajaran Tematik Berbasis Kearifan Lokal Di Sd Muhammadiyah I Malang. Taman Cendekia: Jurnal Pendidikan Ke-SD-An, 2(1), 185-191.

Wibowo, D. A., Poerwanti, E., \& Kuncahyono, K. (2019). Pengembangan Buku Enterdal (Ensiklopedia Tematik Sumber Daya Alam) Tema 3 Peduli Terhadap Makhluk Hidup Untuk Siswa Kelas Iv Sekolah Dasar. Jurnal Holistika, 3(2), 89-98.

Yoan Agustina, D. (2015). Pengembangan Bahan Ajar Interaktif Sebagai Pendukung Implementasi Pembelajaran Berbasis Scientific Approach Pada Materi Jurnal Penyesuaian Siklus Akuntansi Perusahaan Jasa Di SMK Negeri 1 Jombang. Jurnal Pendidikan Akuntansi (JPAK), 3(2). 